\title{
FURTHER OBSERVATIONS ON THE PROTEIN METABOLISM OF NORMAL PREGNANCY *
}

\author{
JOHN R. MURLIN Ph.D., AND HAROLD C. BAILEY, M.D. \\ NEW YORK
}

A few months ago we reported in preliminary form ${ }^{1}$ the results of complete nitrogen partition studies on three carefully controlled normal cases and five pathological cases of pregnancy. We found that some instances of high ammonia could only be explained on the assumption that the bladder had been contaminated by the use of the catheter, and in one case of eclampsia we were able to demonstrate a marked fall in this constituent of the urine by the simple expedient of thoroughly washing the bladder with boric-acid solution twice in twenty-four hours. Because of the obvious importance of this source of error in judging the significance of such findings, we determined to follow up the practice of washing the bladder whenever a high amount of ammonia was encountered. In all properly conducted metabolism studies on the dog, the twenty-four-hour urines are obtained by catheter, by washing out the residual urine with sterile water and then following this with a wash of saturated solution of boric acid. It is self-evident that we should not be content with a less perfect technic in collecting urines from bed-ridden patients, if the analysis of the urine is to be trustworthy. We have, accordingly, selected a number of normal cases, some of which showed an amount of ammonia above the normal, some of them a normal amount, and placing them on constant diets, have observed the effects of a careful irrigation with a quart of boric-acid solution once or twice within an experiment day.

\section{THE COURSE OF THE AMMONIA OCTPUT IN NORMAL PREGNANCY}

We shall present first the urinary findings of two patients who ran perfectly normal courses just before, through and just following labor, the irrigation of whose bladders caused no alteration in the ammonia findings. Such a result can only mean that the bladder was sterile to begin with, and that the use of the catheter introduced no organism capable of splitting urea. The two cases were under the constant sur-

* From the Departments of Physiology and Obstetrics of Cornell University Medical College.

* Submitted for publication June 13, 1913.

* All of the cases here reported were patients in the maternity wards, second division Bellevue Hospital on the service of Dr. J. Clifton Edgar.

1. Murlin and Bailey: Protein Metabolism in Late Pregnancy and the Puerperium, Jour. Am. Med. Assn., 1912, lix, 1522. 
veillance of a special nurse and were maintained on a diet of milk, eggs, bread and butter, potato and ice cream, containing, as shown by the tables, an approximately uniform amount of gross potential energy. The number of calories per kilogram in the tables rises after delivery for the obvious reason that the weight was contantly decreasing. The food was not analyzed, but it is apparent from the total nitrogen figures on the days when a complete twenty-four-hour urine was obtained, that the variation in nitrogen content was not very great. The influence of the total intake of protein and energy, therefore, was reasonably constant throughout.

Before considering the tables, we wish to emphasize the fact that our determinations of the ammonia in these and all other cases have been made by the most approved technic of the Folin method. Folin has recently restated ${ }^{2}$ what the procedure should be. Our water-pump is of the type recommended by him, and gives sufficient pressure to produce an air current which removes all the ammonia from 10 to 20 c.c. of $\mathrm{N} / 10$ $\mathrm{NH}_{4} \mathrm{Cl}$ solution in one hour. This we have verified a number of times in the course of this work. But the aeration for the removal of the ammonia from urine has never been less than four hours, and often was kept up for a much longer time.

It will be seen that the ammonia nitrogen rose in both absolute and relative amounts on the day following labor for both cases (Table 1). In order to make certain that this was not due to contamination of the bladder by the catheter, we had the bladder thoroughly irrigated twice with a saturated solution of boric acid, warmed to body temperature, on the third day of collection by the catheter. The fact that the ammonia did not fall very appreciably the following day, proves that the bladder had been clean. The larger output in both absolute and relative amounts immediately following labor probably is due to the acid products, e. g., lactic acid, ${ }^{3}$ formed and not completely oxidized during labor. We found no trace of acetone bodies at this time, although the total acidity was slightly higher than it had been previously.

In both cases the absolute amount of ammonia continues higher than it was before parturition. With Case 4 (Table 1) the average for the six days on which urine was analyzed previous to delivery is $0.54 \mathrm{gm}$., and for four days after delivery (neglecting the first two on account of the influence of labor), it is $0.76 \mathrm{gm}$. With Case 5 (Table 1 ) it is 0.61 $\mathrm{gm}$. for the two full twenty-four-hour urines before delivery and $0.92 \mathrm{gm}$. for the last six days of the post-partum period (again neglecting the first two days of the puerperium). This difference between antepartum and

2. Folin: Jour. of Biol. Chem., 1912, xi, 523.

3. This sequence is known to occur in phosphorus poisoning. (Lusk: Am. Jour. Physiol., 1907, xix, 461.) 
TabLE 1.-Metabolism Expreiment Showing Coubse of Ammonia Excretion CASE FOUR (S). NORMAL PREGNANCY

\begin{tabular}{|c|c|c|c|c|c|c|c|c|c|c|c|c|}
\hline 芸 & 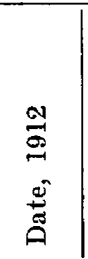 & $\begin{array}{l}\dot{0} \\
\dot{0} \\
\dot{0}\end{array}$ & $\begin{array}{l}\dot{\vec{b}} \\
\dot{\text { Dे }}\end{array}$ & 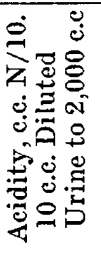 & 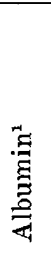 & 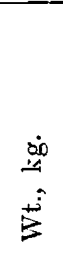 & 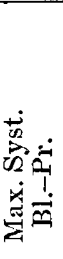 & 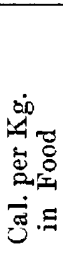 & 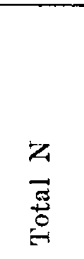 & 㠬 & 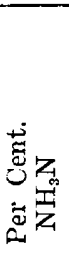 & Remarks \\
\hline & Oct. & & & & & & & & & & & \\
\hline 1 & $28-29$ & 1920 & 1015 & 1.92 & 0 & 78.6 & & & 9.52 & 0.41 & 4.3 & \\
\hline 2 & $29-30$ & 1980 & 1020 & 3.2 & 0 & $\cdots$ & 100 & 42 & 17.94 & 0.73 & 4.1 & \\
\hline 3 & $\begin{array}{l}30-31 \\
\text { Nov. }\end{array}$ & 1540 & 1021 & 3.1 & 0 & $\ldots$ & 90 & 42 & 14.75 & 0.76 & 5.2 & \\
\hline 4 & $31-1$ & $660^{2}$ & 1024 & 2.7 & 0 & $\ldots .$. & 104 & 42 & 6.39 & 0.36 & 5.7 & \\
\hline 5 & 2- 3 & 1350 & & 2.0 & & $\ldots$ & 110 & 42 & 11.87 & 0.53 & 4.5 & \\
\hline 6 & 5. 6 & 1150 & & 1.3 & $\ldots$ & $\ldots$ & 100 & 42 & 8.12 & 0.42 & 5.1 & \\
\hline 7 & $6-7$ & 1100 &. & 2.5 & .... & ..... & 100 & 36 & 10.92 & 0.73 & 6.5 & In labor. \\
\hline 8 & 8. 9 & 1450 & & 3.5 & & $\ldots$. & 115 & 44 & 16.80 & 1.19 & 7.0 & $\begin{array}{l}\text { Delivered } 10 \text { a. m. All } \\
\text { urines by cath. on Nov. } \\
7 \text { and } 8 .\end{array}$ \\
\hline 9 & $9-10$ & 1450 & & 2.3 & & ... & 110 & 45 & 16.07 & 0.84 & 5.2 & All urine by catheter. \\
\hline 10 & 10-11 & 1640 & & 3.1 & & & 105 & 52 & 17.52 & 0.88 & 5.0 & $\begin{array}{l}\text { All urine by catheter. } \\
\text { Bladder washed. }\end{array}$ \\
\hline 11 & $11 \cdot 12$ & 1350 & & 3.0 & $\cdots$ & 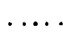 & 107 & 46 & 12.04 & 0.49 & 4.0 & Urine roided spon- \\
\hline 12 & $12-13$ & 1650 & & 3.7 & $\cdots$ & 70.1 & 100 & 47 & 19.88 & 0.84 & 4.2 & $\begin{array}{l}\text { Urine voided spon- } \\
\text { taneously. }\end{array}$ \\
\hline
\end{tabular}

CASE Five (M). NORMaL PREgNancy

\begin{tabular}{|c|c|c|c|c|c|c|c|c|c|c|c|c|}
\hline & Oct. & & & & & & & & & & & \\
\hline 1 & $28-29$ & 2260 & 1061 & 1.06 & + & 61.6 & & & 12.15 & 0.61 & 5.0 & \\
\hline 3 & $29-30$ & $700^{2}$ & 1020 & 2.12 & + & 而 & 138 & 43 & 5.84 & 0.29 & 5.4 & \\
\hline 3 & $\begin{array}{c}30-31 \\
\text { Noy }\end{array}$ & $1750^{2}$ & 1015 & 1.78 & + & & 124 & 43 & 4.98 & 0.25 & 5.2 & \\
\hline 4 & $31-1$ & 1880 & 1017 & 2.1 & ++ & & 108 & 43 & 11.59 & 0.62 & 5.3 & $\begin{array}{l}\text { Labor Nov. 3-5. Del. Nov. } \\
\text { 5th, } 3 \text { a. m. }\end{array}$ \\
\hline 5 & 5- 6 & 2000 & $\ldots$ & 2.3 & ++ & & 142 & 40 & 12.86 & 1.28 & 10.0 & All urine by catheter. \\
\hline 6 & 6- 7 & 2000 & & 1.7 & ++ & & 138 & 38 & 11.39 & 0.88 & 7.7 & All urine by catheter. \\
\hline 7 & 7- 8 & 1100 & & 1.8 & $+\dot{t}$ & & 128 & 47 & 17.69 & 1.17 & 6.6 & $\begin{array}{l}\text { All urine by catheter. } \\
\text { Bladder washed. }\end{array}$ \\
\hline 8 & 8. 9 & 1850 & & 2.5 & ++ & & 116 & 48 & 15.98 & 0.98 & 6.1 & $\begin{array}{l}\text { Urine spontaneously and } \\
\text { by catheter. }\end{array}$ \\
\hline 9 & $9-10$ & 1650 & & 2.5 & + & & 122 & 49 & 14.89 & 0.79 & 5.3 & $\begin{array}{l}\text { Urine spontaneously and } \\
\text { by catheter. }\end{array}$ \\
\hline 10 & $10-11$ & 1400 & & 3.3 & + & & 118 & 50 & 17.08 & 1.05 & 6.1 & Voided spontaneously. \\
\hline 11 & $11-12$ & 1320 & & 2.0 & + & & 114 & 51 & 16.97 & $0.7 \pi$ & 4.5 & Voided spontaneously. \\
\hline 12 & $12-13$ & 1700 & .. & 3.2 & + & 52.4 & 125 & 52 & 16.97 & 0.79 & 4.7 & Voided spontaneously. \\
\hline
\end{tabular}

1. Acetone and diacetic acid absent.

2. Some urine lost. 
post-partum urines in general is not due to a difference in the food. It may possibly be due to the autolysis of the uterus accompanied by the liberation of acid bodies which must be neutralized by ammonia.

The resolution of the uterus results in a gradual increase in the total output of urinary nitrogen for several days, and a greater increase on the sixth day in both cases. This confirms again the observation of Longridge, ${ }^{4}$ which one of $\mathrm{us}^{5}$ had already confirmed in normal cases. Because of the higher total nitrogen excretion, the percentage of the ammonia nitrogen does not increase. In fact, it is even lower for Case 4 on the days which have been averaged for the absolute amount than before delivery ( 4.6 per cent. as against 4.8 per cent.). In Case 5 the average for the post-partum urines, not influenced by parturition, is 5.6 per cent., and for the two full days ante-partum it is 5.2 per cent. On the whole, one may say that the percentage of ammonia nitrogen in the urine is almost the same during the puerperium as immediately before delivery.

\section{EFFEC'T OF FOUL BLADDER}

Contrasted. with the above results are those presented in Table 2 for Cases 6 and 7 . These are both normal pregnancies, no symptoms having been noted or complained of at any time previous to or immediately following our observations. Like Cases 4 and 5 , they were kept on special diets, consisting of milk, eggs, bread and butter, custard and boiled rice and containing approximately 2,100 calories. The records show that the amounts taken each day were nearly the same. Case 6 had at the beginning of our observations $2 \mathrm{gm}$. of ammonia nitrogen in the urine. This fell gradually for about a week, when it had reached the level shown on the first day of the table. The striking thing about the chart, however, is the enormous fall in the ammonia nitrogen which resulted from washing the bladder on the second day following delivery. The interpretation of the rest of the chart must obviously be made in the light of this effect. Microscopical examination of the urines obtained before delivery, but made subsequent to the discovery of the contamination, revealed the presence of many bacteria and some pus cells, but it was a case which, without the confirmatory evidence of the effects of irrigation, might have been allowed to pass as an "unexplained" high ammonia.

No doubt a part of the high ammonia on the day of delivery and the day after may be ascribed, as we have just seen, to the effects of labor itself, but so great a fall-from $2.27 \mathrm{gm}$. ammonia nitrogen to $1.33 \mathrm{gm}$.can only be attributed to the cleansing which the bladder received. It happens that the total nitrogen in the urine October 2 to 3 and October 4 to 5 is nearly the same, so that the fall to 9 per cent. in this total in the

4. Longridge: Jour. Obst. and Gynecol., 1908, xiii, 420.

5. Murlin: Surg., Gynecol. and Obst., January, 1913, p. 43. 
ammonia fraction cannot be referred to a change in the diet, nor, since the autolysis is not yet far enough advanced, to a change in the uterus. That the extra ammonia came largely if not wholly from the decomposition of urea is shown by the sums of the urea and ammonia fractions for these days; and that the decomposition took place in the bladder and not in the bottle we are certain, because of the fact that the preservative

TABLE 2.-Experiments Illustrating Influence of Foul Bladder CASE SIX (R). NORMAL PREGNANCY

\begin{tabular}{|c|c|c|c|c|c|c|c|c|c|c|c|}
\hline 完 & 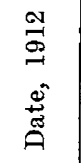 & 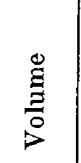 & $\begin{array}{l}\dot{0} \\
\dot{0}\end{array}$ & 总 & 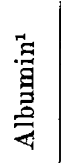 & 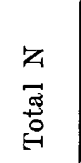 & $\begin{array}{l}\text { 乙 } \\
\$ \\
\vdots \\
\vdots\end{array}$ & $\begin{array}{l}z_{\infty} \\
\text { 夏 }\end{array}$ & 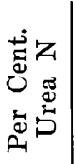 & 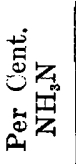 & Diet and Condition of Patient \\
\hline 1 & $\begin{array}{l}\text { Sept. } \\
27-28\end{array}$ & 1670 & & 1.30 & Tr. & 12.37 & 9.29 & 1.78 & 75.1 & $14.3^{2}$ & $\begin{array}{l}\text { Special diet of milk, eggs, bread } \\
\text { and butter, custard and boiled } \\
\text { rice, containing about } 2,100 \\
\text { calories. }\end{array}$ \\
\hline 2 & $28-29$ & 1380 & & 0.80 & $\operatorname{Tr}$. & 9.72 & 7.48 & 1.10 & 76.8 & 11.3 & \\
\hline 3 & $\begin{array}{l}28-29 \\
\text { Oct. }\end{array}$ & 1530 & & 2.0 & . & 13.00 & 10.04 & 1.35 & 77.2 & 10.3 & \\
\hline 4 & 2- 3 & 1860 & 1021 & 1.9 & & 14.71 & 10.60 & 2.27 & 72.0 & 15.4 & $\begin{array}{l}\text { Baby born Oct. 2. Catheter } \\
\text { used six hours. }\end{array}$ \\
\hline 6 & $4-5^{5}$ & 1230 & 1023 & $0.3_{5}$ & 0 & 14.08 & 10.56 & 1.33 & 75.0 & 9.4 & Bladder washed. \\
\hline 7 & $5-6$ & $950^{\circ}$ & 1020 & 1.75 & 0 & 12.41 & 9.45 & 1.08 & 76.4 & 8.7 & \\
\hline
\end{tabular}

Case seven (T). NORMal PRegnancy

\begin{tabular}{|c|c|c|c|c|c|c|c|c|c|c|c|}
\hline 1 & $24-25$ & 1800 & $\ldots$ & 2.3 & 0 & 13.38 & 10.58 & 1.07 & 79.0 & 8.0 & $\begin{array}{l}\text { Third day postpartum; second } \\
\text { day of using catheter. Spe- } \\
\text { cial diet of milk, eggs, bread } \\
\text { and butter, cus a rd a nd } \\
\text { boiled rice containing about } \\
2,100 \text { calories. }\end{array}$ \\
\hline 2 & $25-26$ & 950 & & 1.4 & 0 & 11.39 & 9.20 & 0.82 & 80.7 & 7.2 & Bladder washed. \\
\hline 3 & $26-27$ & 1430 & & 0.8 & 0 & 13.34 & 10.52 & 0.68 & 78.8 & 5.1 & \\
\hline
\end{tabular}

1. Acetone and diacetic acid absent.

2. In this case bacteria were found in urine before parturition:

3. The urine for October 3-4 was alkaline and is therefore not considered.

was placed in the bottle before it left the laboratory each day and because of the care which was constantly exhibited by the nurse who had charge of these cases.

Case 7 will be readily understood from the table. The fall neither in absolute nor in percentage amounts in this case is so great when the bladder was washed as it was in Case 6 , but there seems to be no other explanation; for the total nitrogen in the urine was the same, and there were no unusual acid bodies in the urine which we could detect. 
We have included only these two cases which showed a fall in the urinary ammonia, because they were the only ones which exhibited the same total nitrogen before and after irrigation. Several other cases were observed in which the effect of irrigation was evident. It would be foolish to assert that no clean urine can be obtained from parturient patients without washing the bladder, but it is clear from our experience that this possible source of contamination must now be placed alongside of others (passage of the urine over the vulva, mixture with feces, lochia, etc.), which have always been recognized. We believe the safest and surest way to avoid all dangers of contamination is the manner of collection which we have adopted, namely, drawing the urine by catheter and placing it directly into the bottle containing preservative, and washing the bladder thoroughly with boric-acid solution twice in twenty-four hours immediately following catheterization. The boric-acid wash should not be mixed with the urine, because it interferes with certain determinations. A perfectly exact termination of the twenty-four-hour period is only thus obtainable, for by suitable manipulation of the catheter the bladder can be emptied more completely than is usually possible by the voluntary efforts of a parturient woman. A first wash with sterile distilled water is advisable, in order to obtain the last traces of urine in the bladder. The procedure should be so timed that it terminates on the last moment of the twenty-four-hour period.

While this routine may seem to some unnecessary, we are certain from long experience in metabolism experiments with animals that it is the only scientific procedure in metabolism studies with bed-ridden patients.

\section{COMPLETE NITROGEN PARTITIONS}

Tables 3, 4 and 5 contain the complete analyses for the three normal cases whose metabolism was reported in summary in the previous paper. Several points of interest may be seen in the day-to-day record. For example, the influence of the changes in diet from "ordinary hospital fare" containing meat to a diet consisting largely of milk, can be seen especially in the columns for ammonia, creatin and total purin nitrogen; and the variation in all the fractions which occur normally, or the range of error, as the case may be, is exhibted.

\section{METHODS OF ANALYSIS}

Total nitrogens were determined by the Kjeldahl method, using Folin's sulphate mixture for hydrolysis; urea-plus-ammonia by Benedict's method; ammonia as already stated; creatinin and creatin by Folin's colorimetric method, converting creatin to creatinin in 500 c.c. flasks provided with pipet condensers and kept on the electric stove just

6. Benedict: Jour. of Biol. Chem., 1911, viii 405. 
below boiling for three hours; total purin by a modification of Hall's ${ }^{7}$ sedimentation method, which is in principle the old Camerer-Arnstein method of precipitation with silver; and amino-acids by a modification of the "new" formalin titration method introduced by Henriques and Sörensen. ${ }^{8}$ Only the two last-named methods require any comment.

\section{TOTAL PURIN METHOD}

We began with Hall's purinometer, but owing to the fact that the purinometer can be used for only one determination in twenty-four hours, if results at all accurate are to be obtained, we have adapted the method to the use of the centrifuge as follows: 14 c.c. of urine (the twenty-four-hour urine diluted to 2,000 c.c.), is placed in a graduated centrifuge tube and 2 c.c. of Hall's purinometer, solution No. 1, is added and the resulting precipitate centrifuged. From the supernatent fluid 11.43 c.c. (equals 10 c.c. urine) is then measured into another centrifuge tube and 2 c.c. of strong ammonia and 2 c.c. of 3 per cent. silver nitrate solution are added. This mixture should stand for one-half hour or more to allow complete reaction. A centrifuge running at 1,800 revolutions per minute will throw down all the silver-purin in about twenty minutes. This precipitate is then stirred up with a glass rod and is washed twice with a 1 per cent. solution of ammonia, being thrown down each time by running the centrifuge for about five minutes. Finally it is washed into a Kjeldahl flask, the ammonia is boiled off with magnesium oxid and the regular Kjeldahl procedure follows for direct determination of the nitrogen. Titration is best accomplished with N/50 NAOH solution.

With a six-arm centrifuge the method is fairly rapid and is certainly not less accurate than the original Camerer-Arnstein method or any of its many earlier modifications. This we have satisfied ourselves of by use of pure uric acid, xanthin and hypoxanthin.

\section{AMINO-ACID METHOD}

The amino-acid fraction was determined at first by only a slight modification of the so-called "new" method of Henriques and Sörensen. This modification consisted only in driving off the ammonia by the aeration method of Folin, running the most rapid current of air obtainable with a suction pump (nearly always over night, eighteen hours). Controls with $\mathrm{NH}_{4} \mathrm{Cl}$ solution in equal volume of water $(50$ c.c.) convinced us after a time that we were not getting quite all the ammonia especially in urines containing much of it, and this conclusion led us to adopt a different method of removing the ammonia; namely, by precipitation with phosphotungstic acid. ${ }^{9}$

The method which we now use is as follows: Take 200 c.c. of urine and add an equal volume of 10 per cent. phosphotungstic acid in 2 per cent. HCl. Allow to sediment for at least four hours (better over night). Pour off 200 c.c. of the supernatant fluid into a 250 c.c. flask, add 1 c.c. of 1 per cent. phenolphthalein and saturated solution of barium hydrate, or barium hydrate in substance, until the solution turns decidedly pink. Make up to 250 c.c. with water, stopper, shake up thoroughly and let stand for two hours. Filter off two 100 c.c. samples (equals 40 c.s. urine each) for duplicate titrations, and follow the regular Henriques and Sörensen procedure observing all precautions. ${ }^{10}$

7. Hall, I. Walker: The Purin Bodies of Foodstuffs, 1903, p. 149.

8. Henriques and Sörensen: Ztschr. f. physiol. Chemie, 1910, lxiv, 120.

9. Benedict and Murlin: Proc. Soc. for Exper. Biol. and Med., 1912, ix, 109.

10. For a good critique of this method see "Die Formoltitration," by $H$. Jessen-Henson in Abderhalden's Arbeitsmethoden, 1913, vi, 262. 


\section{DISTRIBUTION OF THE NITROGEN IN THE URINE OF NORMAL} PREGNANCY

The data regarding the blood-pressures, temperatures, pulse and respiration in Tables 3,4 and 5 should be convincing evidence, when taken in connection with the absence of symptoms, that these three cases were entirely normal in every respect. All of the patients were in the last month of pregnancy. They were placed in a separate ward under the care of a nurse whose main occupation was the supervision of their diets and the collection of their urines. The women did no work and were practically in a condition of rest during the course of these observations.

On the first two days and the fourteenth or last day of the observation period, they were kept on a regular ward diet which contained meat. From the third to the ninth day inclusive they received a diet of whole milk, bread and butter, and a constant amount of milk-sugar. An effort was made to keep the calories supplied proportional to the requirements of the individuals; but in this we did not wholly succeed. The requirements for women in the last few weeks of pregnancy, who are resting quietly in bed, has been found by Carpenter and Murlin,, ${ }^{11}$ by means of both the direct and the indirect methods of calorimetry, to be in the neighborhood of 30 calories per kilogram. For a fat woman it would not be more than 27 calories per kilogram.

We estimated the requirement for these patients sitting up part of the time and moving about the ward, to be not over 35 calories per kilogram. Only one (Case 2) of the three took that quantity of food for any length of time, and is the only one that shows a distinct gain in weight. But for the severe catharsis given on December 16, the patient would probably have finished the two-weeks period a couple of pounds heavier than at the start. That all of the patients were fairly well nourished, however, and that the children did not suffer, is shown by the fact that within three weeks all came to parturition and delivered children weighing as follows: Case 1, 9 pounds, 4 ounces; Case 2, 9 pounds, 8 ounces; Case 3,7 pounds, 2 ounces.

In our preliminary paper and in a more recent contribution ${ }^{5}$ by one of us, the general physiological significance of the different nitrogen fractions has been sufficiently considered. The questions that require further evidence and discussion are: To what extent does pregnancy of itself alter the distribution of the nitrogen, and can such alterations be accounted for on purely physiological grounds?

To answer the first question with any approach to accuracy it is necessary to compare the metabolism between the pregnant and the nonpregnant states either in the same individual or in different individuals

11. Carpenter and Murlin: The Energy Metabolism of Mother and Child Just Before and Just After Birth, The Archives Int. Med., 1911, vii, 184. 
in the same general health, age, etc.; and in either case on the same diet. It is desirable that the nitrogen balance should be known so that the influence of nitrogen retention may be observed. For the dog these conditions have been rigorously met by following the metabolism on the same diet throughout the entire gestation period. ${ }^{12}$ For the woman, in addition to our studies, a paper by Landsberg ${ }^{13}$ has appeared recently in which the author compares the metabolism as to the urea, ammonia and amino-acid nitrogens of six non-pregnant women with that of ten normally pregnant women, all kept on similar diets. Nitrogen, sulphur and phosphorus balances were kept. Heynemann ${ }^{14}$ has done the same, omitting the balance studies, for the creatin and creatinin. Falk and Hessky ${ }^{15}$ a short time before had made analyses for ammonia, amino-acid and polypeptid nitrogens in the urines of both pregnant and non-pregnant women, but their conditions were apparently not so carefully controlled.

We believe that we now have in these researches, together with our own, sufficient data to enable one to forecast pretty definitely for the last weeks of a normal pregnancy (for a woman whose intake of food is known and is sufficient to meet her requirements), what the distribution of the nitrogen should be.

\section{UREA NITROGEN}

It is now demonstrated $d^{5,12}$ that the retention of nitrogen in pregnancy will cause a diminution in the absolute amount of urea excreted. Both in dogs and in women it is found that where retention of nitrogen is known to be greater, or where the conditions for nitrogen retention are known to be present, the urea falls. The percentage fall is even greater than the absolute fall, because, as we shall see later, certain other nitrogenous constituents of the urine are slightly increased.

Landsberg's experiments unfortunately are largely invalidated so far as the urea determinations are concerned by the method employed; namely, taking the total nitrogen in the filtrate after removal of ammonia and precipitation with alcohol and ether (Spiro's method). Multiplying this amount of nitrogen by $15 / 7$ is said to give the urea nitrogen. This method has long been known ${ }^{16}$ to yield all of the creatinin and hippuric acid nitrogen, part of the uric acid and probably a large part of the creatin nitrogen (which is nearly always present in the urine of late pregnancy), in addition to the urea nitrogen. Landsberg's estimate of the fraction ( 82 to 86 per cent.) is therefore certainly too high, possibly as much as 6 or 7 per cent. However, even by this method, he finds the

12. Murlin: Am. Jour. Physiol., 1911, xxviii, 422.

13. Landsberg: Ztschr. f. Gebürtsh. u. Gynäk., 1912, lxxv, 163.

14. Heynemann: Ztschr. f. Geburtsh. u. Gynäk., 1912, lxxv, 110.

15. Falk and Hessky: Ztschr. f. klin. Med., 1910, lxxi, 261.

16. Howe and Hawk: Comparative Tests of Spiro's and Folin's Methods for the Determination of Ammonia and Urea. Jour. Biol. Chem., 1909, v, 477. See also Neubauer and Huppert's Analyse des Harns, 1910, p. 574. 
average percentage for normal pregnancy (83.6 per cent.) lower than for normal non-pregnant women ( 85.02 per cent.).

The three normal cases here reported show an average of 77.8 per cent., 70.8 per cent. and 81.4 per cent., respectively. (Tables 3,4 and 5. . $^{\mathbf{1 7}}$ The lowest percentage occurs in the urine of the patient (Case 2), who received most nearly her requirement of food, who gained most in weight and was therefore probably retaining most nitrogen. The next lowest occurs in the patient (Case 1), who received the medium amount of food; and, as the figures stand, the highest percentage occurs in the case (3) that received the lowest amount of food per unit of weight. It is probable, however, that the average for Case 3 is too high (see note at bottom of table).

The same relationship holds also for the urea-plus-ammonia nitrogen, i. e., for all the nitrogen that comes from the end-products of protein digestion or from putrefaction in the alimentary canal. Such a relationship would not hold if the factor of undernutrition, which Folin ${ }^{18}$ has shown to play an important part in determining the percentage of urea, ammonia, etc., entered here.

The urea average for the whole antepartum period, taking the three cases together, is 76.6 per cent. For the three cases reported by Murlin ${ }^{5}$ it was 75.6 per cent. The range in all six cases is from 70.8 (Case 2 this series) to 79.4 (Case 1 former series). Taking urea and ammonia together or "total-amid nitrogen" the average for this series is 84.2 per cent.; for the former series 82.5 per cent. The range is from 80.3 (Case 2 this series) to 86.7 (Case 3 former series).

\section{AMMONIA NITROGEN}

'These tables show something of the range that may be expected in the ammonia excretion from normal cases four to six weeks before delivery. Case 1 shows an average of 0.74 gm., 6.9 per cent. of the total nitrogen; Case 2, 0.54 gm., 10.3 per cent. of the total, and Case 3, 0.51 gm., or 5.3 per cent. of the total. Landsberg finds as the results of about four days' examination on ten patients that the average of all is $0.786 \mathrm{gm}$. ammonia nitrogen, or 6.8 per cent. as contrasted with $0.771 \mathrm{gm}$., or 4.3 per cent. from six non-pregnant women on a similar diet. Landsberg does not lay special stress on the fact that the absolute amount is but slightly higher and that the difference in percentage is really due to the larger output of total nitrogen (16.03 $\mathrm{gm}$. in the non-pregnant subject, as compared with $12.68 \mathrm{gm}$. in the pregnant). Falk and Hessky, among the later observers, also found the relation of the ammonia nitrogen to the total nitrogen "higher than the figures which are assumed to be normal on a

17. The averages in these tables differ slightly from the averages published in our preliminary paper because three more days are here included.

18. Folin: Am. Jour. Physiol., 1905, xiii, 66. 
TABLE 3.-Results of Metabolism Experiment in

\begin{tabular}{|c|c|c|c|c|c|c|c|c|c|c|c|c|c|}
\hline \multirow[b]{2}{*}{$\dot{0}$} & \multirow[b]{2}{*}{ 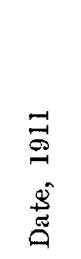 } & \multicolumn{5}{|c|}{-Condition of Patient- } & \multirow[b]{2}{*}{ Diet } & \multicolumn{6}{|c|}{$\longrightarrow$ Qualitative Examination- } \\
\hline & & 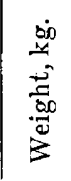 & $\begin{array}{l}A_{1}^{+} \\
\dot{0} \\
\dot{0} \\
0\end{array}$ & 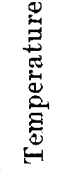 & $\underset{D}{0}$ & 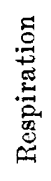 & & 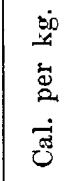 & $\frac{0}{0}$ & 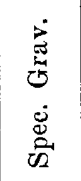 & 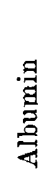 & 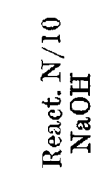 & \\
\hline & Dec. & & & & & & & & & & & & \\
\hline 1 & $5 \cdot 6$ & . & & 97.8 & 108 & 22 & Ordinary hospital fare... & $\cdots \cdots$ & 1050 & 1031 & Tr. & Ac. 5 & \\
\hline 2 & 6- 7 & & 115 & 97.8 & 88 & 22 & Ordinary hospital fare... & & 980 & 1032 & Tr. & Ac. 5 & c.c. \\
\hline 3 & $7-8$ & . & 120 & 97.8 & 92 & 22 & Milk, bread and butter.. & 18 & 768 & 1034 & 0 & Ac. & \\
\hline 4 & 8- 9 & 75.0 & 118 & 97.8 & 96 & 22 & Milk, bread and butter.. & 24 & 800 & 1035 & 0 & Ac. & \\
\hline 5 & $9-10$ & 75.0 & 116 & 98.0 & 92 & 22 & Milk, bread and butter. & 20 & 860 & 1035 & 0 & Ac. 6 & c.c. \\
\hline 6 & $10-11$ & 75.0 & 110 & 98.0 & 96 & 24 & Milk, bread and butter. . & 29 & 830 & 1030 & 0 & Ac. 6 & c.c. \\
\hline 7 & $11-12$ & 74.5 & 96 & $9 b$ & 96 & 24 & Milk, bread and butter.. & 33 & 750 & 1033 & 0 & Ac. 9 & c.c. \\
\hline 8 & $12-13$ & 75.4 & 108 & 98 & 88 & 24 & Milk, bread and butter ${ }^{3}$. & 37 & 930 & 1034 & 0 & Ac. 6.8 & c.c. \\
\hline 9 & $13-14$ & 75.4 & 108 & 97.8 & 92 & 24 & Milk, bread and butter ${ }^{3}$. & 36 & 1085 & 1030 & 0 & Ac. & \\
\hline 10 & $14-15$ & 75.0 & 118 & 98 & 92 & 24 & Milk and starchy foods ${ }^{2}$. & 31 & 1250 & 1028 & 0 & Ac. & \\
\hline 11 & $15-16$ & 74.8 & 118 & 97.8 & 104 & 22 & Milk and starchy foods ${ }^{2}$. & 31 & 585 & 1026 & 0 & Ac. & \\
\hline 12 & $16-17$ & 75.0 & 114 & 98 & 96 & 22 & Milk and starchy foods ${ }^{2}$. & 31 & 635 & 1028 & 0 & Ac. & \\
\hline I3 & $17-18$ & 75.0 & 110 & 98 & 102 & 24 & Milk and starchy foods ${ }^{2}$. & 31 & 1010 & 1026 & 0 & Ac. & \\
\hline 14 & $18-19$ & 74.8 & 110 & 98 & 104 & 24 & Ordinary hospital fare... & $\ldots$. & 1360 & 1021 & $\mathbf{0}$ & Ac. & \\
\hline
\end{tabular}

Average

1. Urine bottle broken.

2. Oatmeal, bread, graham crackers, baked potato.

TABLE 4.-Results of MEtabolis.m Experiment iN

\begin{tabular}{|c|c|c|c|c|c|c|c|c|c|c|c|c|}
\hline \multirow[b]{2}{*}{ 字 } & \multirow[b]{2}{*}{ 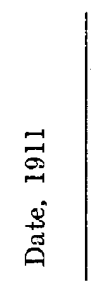 } & \multicolumn{5}{|c|}{- Condition of Patient $\longrightarrow$} & \multirow[b]{2}{*}{ Diet } & \multicolumn{5}{|c|}{$\begin{array}{l}\text { Urine } \\
\text { Qualitative Examination }\end{array}$} \\
\hline & & 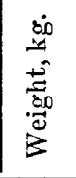 & $\begin{array}{l}\dot{\overrightarrow{1}} \\
\dot{\ddot{g}} \\
\dot{8} \\
\dot{0}\end{array}$ & 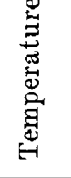 & 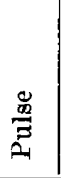 & 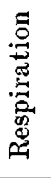 & & $\begin{array}{l}\dot{00} \\
\dot{y} \\
\dot{\Delta} \\
\dot{0} \\
\dot{0}\end{array}$ & $\frac{\stackrel{D}{\Xi}}{0}$ & 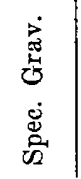 & & 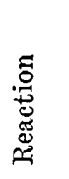 \\
\hline 1 & Dec. & & & & & & & & & & & \\
\hline 2 & 6- 7 & & $\because 30$ & 97.8 & $\begin{array}{l}110 \\
112\end{array}$ & $\begin{array}{l}24 \\
22\end{array}$ & $\begin{array}{l}\text { Urdinary hospital tare.. } \\
\text { Ordinary hospital fare... }\end{array}$ & & $\begin{array}{r}1550 \\
960\end{array}$ & $\begin{array}{l}1016 \\
1016\end{array}$ & $\begin{array}{c}\Gamma r . \\
0\end{array}$ & $\begin{array}{l}\text { Ac. }{ }^{1} \\
\text { Ac. }\end{array}$ \\
\hline 3 & 7- 8 & & 140 & 98 & 110 & 22 & Milk, bread and butter...... & 24 & 932 & 1020 & 0 & Ac. \\
\hline 4 & 8- 9 & 65.4 & 115 & 98 & 112 & 22 & Milk, bread and butter....... & 28 & 812 & 1018 & Tr. & Ac. \\
\hline $\mathbf{5}$ & $9-10$ & 65.0 & 112 & 97.8 & 112 & 22 & Milk, bread and butter....... & 21 & 700 & 1020 & Tr. & Ac. \\
\hline 6 & $10-11$ & 65.0 & 106 & 97.8 & 128 & 32 & Milk, bread and butter...... & 26 & 710 & 1020 & 0 & Ac. \\
\hline 7 & $11-12$ & 65.0 & 105 & 98 & 100 & 24 & Milk, bread and butter....... & 27.5 & 540 & 1017 & 0 & Ac. \\
\hline 8 & $12-13$ & 65.9 & 112 & 98.2 & 96 & 24 & Milk, bread and butter ${ }^{4}$. & 38.3 & 740 & 1018 & Tr. & Ac. \\
\hline 9 & $13-14$ & 65.9 & 114 & 98 & 88 & 24 & Milk, bread and butter... & 33.5 & 650 & 1020 & Tr. & Ac. \\
\hline 10 & $14-15$ & 65.7 & 116 & 98.2 & 84 & 22 & Milk and starchy foods ${ }^{2}$. & 35 & 750 & 1018 & Tr. & Ac. \\
\hline 11 & $15-16$ & 65.7 & 122 & 98 & 112 & 24 & Milk and starchy foods.... & $\mathbf{3 5}$ & 610 & 1026 & 0 & Ac. \\
\hline 12 & $16-17$ & 65.9 & 118 & 98.2 & 100 & 22 & Milk and starchy foods....... & 35 & $420^{3}$ & 1024 & 0 & Ac. \\
\hline 13 & $17-18$ & 65.0 & 106 & 98 & 96 & 22 & Milk and starchy foods....... & 35 & 720 & 1022 & Tr. & Ac. \\
\hline 14 & $18-19$ & 65.4 & 110 & 98.2 & 100 & 22 & Ordinary hospital fare....... & $\ldots$ & 1130 & 1014 & Tr: & Ac. \\
\hline
\end{tabular}

Average

1. Acetone and diacetic acid absent throughout. 2. Oatmeal, bread, graham crackers, baked 
Normal Pregnancy. Case 1 (B. H.) Ninth Month

Quantitative Urine Analysis of Nitrogen Fractions

\begin{tabular}{|c|c|c|c|c|c|c|c|c|c|c|c|c|c|c|}
\hline 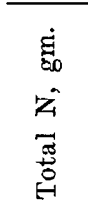 & 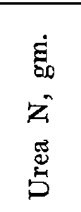 & 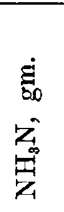 & $\begin{array}{l}\tilde{g}_{0} \\
z \\
z \\
\dot{E}\end{array}$ & $\begin{array}{l}\dot{g_{0}} \\
z_{i=\infty}^{n} \\
\dot{0}\end{array}$ & 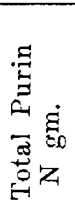 & 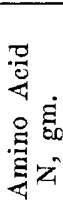 & 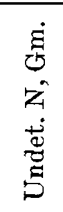 & 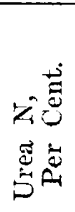 & 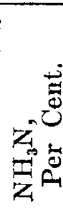 & 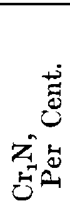 & 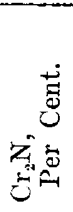 & 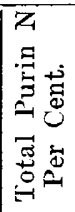 & 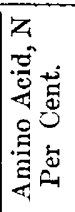 & 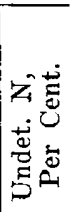 \\
\hline 15.06 & 11.43 & 0.83 & 0.41 & 0.13 & 0.22 & & & 75.9 & 5.5 & 2.7 & 0.9 & 1.4 & & \\
\hline 12.88 & 9.90 & 0.74 & 0.35 & 0.19 & & 0.37 & & 76.9 & 5.7 & 2.7 & 1.5 & & 2.9 & \\
\hline 11.54 & 8.91 & 0.78 & 0.39 & 0.15 & 0.41 & 0.40 & 0.42 & 77.2 & 6.8 & 3.4 & 1.3 & 4.2 & 3.5 & 3.6 \\
\hline 10.86 & 8.73 & 0.68 & 0.37 & 0.14 & 0.31 & 0.43 & 0.20 & 80.4 & 6.3 & 3.4 & 1.3 & 2.8 & 4.0 & 1.8 \\
\hline 11.37 & 8.76 & 0.71 & 0.38 & 0.06 & 0.25 & 0.34 & 0.88 & 77.0 & 6.2 & 3.3 & 0.5 & 2.2 & 3.0 & 7.8 \\
\hline 11.28 & 8.70 & 0.71 & 0.34 & 0.07 & 0.28 & 0.35 & 0.92 & 77.1 & 8.1 & 3.0 & 0.6 & 2.4 & 3.1 & 8.1 \\
\hline 12.07 & 9.27 & 0.88 & 0.40 & 0.08 & 0.28 & 0.50 & 0.66 & 76.8 & 9.4 & 3.3 & 0.7 & 2.3 & 4.1 & 5.4 \\
\hline .43 & 9.48 & 0.88 & 0.36 & 0.09 & 0.36 & 0.45 & 0.81 & 76.3 & 7.1 & 2.9 & 0.7 & 2.9 & 3.6 & 6.5 \\
\hline 13.33 & 10.54 & 0.88 & 0.38 & 0.05 & & 0.47 & & 79.2 & 6.6 & 2.9 & 0.4 & & 3.6 & \\
\hline 15.57 & 12.99 & 0.78 & 0.41 & 0.16 & 0.64 & 0.53 & 0.04 & 83.4 & 5.0 & 2.6 & 1.3 & 4.1 & 3.4 & 0.2 \\
\hline 9.02 & 7.21 & 0.57 & 0.27 & 0.19 & & 0.59 & 0.19 & 80.0 & 6.3 & 3.0 & 2.2 & & 6.5 & 2.1 \\
\hline 8.06 & 6.25 & 0.58 & 0.28 & 0.06 & 0.36 & 0.47 & 0.06 & 77.5 & 7.2 & 3.5 & 0.7 & 3.5 & 5.8 & 1.6 \\
\hline 10.98 & 8.17 & 0.71 & 0.32 & 0.20 & 0.31 & 0.63 & 0.64 & 74.4 & 6.5 & 2.9 & 1.8 & 2.8 & 5.7 & 2.9 \\
\hline 8.29 & 6.45 & 0.83 & 0.38 & 0.09 & 0.67 & 0.61 & 0.75 & 77.8 & 10.0 & 4.6 & 1.1 & 8.1 & 7.4 & 9.0 \\
\hline 11.61 & 9.30 & 0.74 & 0.38 & 0.12 & 0.37 & 0.47 & 0.55 & 77.8 & 6.9 & 3.2 & 1.1 & 3.3 & 4.4 & 4.4 \\
\hline
\end{tabular}

3. Fifteen gr. thyroid extract daily.

Normal Pregnancy. Case 2 (M. L.) Ninth Month

Quantitative Urine Analysis of Nitrogen Fractions

\begin{tabular}{|c|c|c|c|c|c|c|c|c|c|c|c|c|c|c|}
\hline 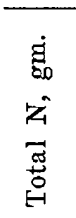 & 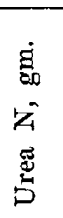 & 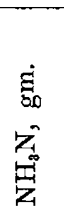 & 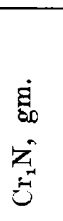 & 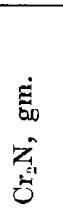 & 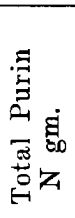 & 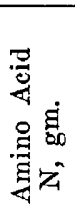 & 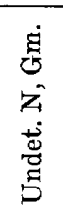 & 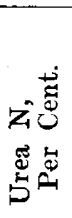 & 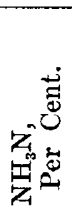 & 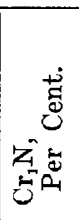 & 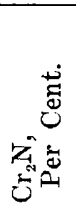 & 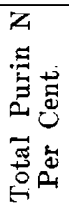 & 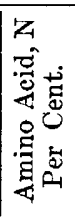 & 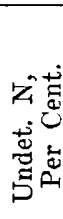 \\
\hline 9.01 & 6.52 & 0.76 & 0.42 & 0.0 & 0.75 & 0.29 & 0.27 & 72.3 & 8.4 & 4.7 & 0.0 & 8.3 & 32 & 3.0 \\
\hline 6.49 & 4.90 & 0.51 & 0.27 & 0.05 & 0.43 & 0.15 & 0.18 & 76.5 & $\begin{array}{l}0.4 \\
7.9\end{array}$ & $\begin{array}{l}4.6 \\
4.2\end{array}$ & 0.7 & $\begin{array}{l}0.0 \\
3.0\end{array}$ & $\begin{array}{l}0.4 \\
2.4\end{array}$ & $\begin{array}{l}0.0 \\
2.8\end{array}$ \\
\hline 6.49 & 4.72 & 0.65 & 0.35 & 0.06 & 0.34 & 0.28 & 0.09 & 72.7 & 10.0 & 5.4 & 0.9 & 5.2 & 4.3 & 1.4 \\
\hline 5.45 & 4.02 & 0.51 & 0.28 & 0.11 & 0.25 & 0.26 & 0.03 & 73.7 & 9.3 & 5.1 & 2.0 & 4.6 & 4.8 & 0.4 \\
\hline 4.65 & 3.28 & 0.47 & 0.24 & 0.0 & 0.22 & 0.37 & 0.07 & 70.6 & 10.1 & 5.2 & 0 & 4.7 & 7.9 & 1.5 \\
\hline 5.71 & 4.17 & 0.53 & 0.28 & 0.0 & 0.08 & 0.28 & 0.37 & 72.8 & 9.3 & 4.9 & 0 & 1.4 & 4.9 & 6.4 \\
\hline 3.42 & 2.38 & 0.36 & 0.14 & 0.0 & 0.22 & 0.18 & 0.14 & 69.7 & 10.5 & 4.1 & 0 & 6.4 & 5.3 & 4.0 \\
\hline 5.38 & 3.91 & 0.60 & 0.17 & 0.0 & 0.25 & 0.24 & 0.21 & 72.6 & 11.2 & 3.2 & 0 & 4.6 & 4.4 & 3.9 \\
\hline 4.8 & 3.35 & 0.59 & 0.16 & 0.13 & 0.20 & 0.20 & 0.18 & 67.6 & 12.2 & 3.3 & 2.7 & 4.2 & 4.2 & 3.7 \\
\hline 5.10 & 3.55 & 0.54 & 0.22 & 0.11 & 0.28 & 0.35 & 0.05 & 69.6 & 10.6 & 4.3 & 2.2 & 5.5 & 6.9 & 0.9 \\
\hline 5.82 & 4.13 & 0.57 & 0.21 & 0.0 & 0.31 & 0.20 & 0.41 & 70.9 & 9.8 & 3.6 & 0.0 & 5.3 & 3.4 & 7.0 \\
\hline 3.36 & 2.11 & 0.58 & 0.23 & 0.0 & 0.17 & 0.26 & 0.11 & 63.8 & 17.3 & 3.9 & 0 & 5.1 & 7.7 & 3.3 \\
\hline 5.71 & 3.98 & 0.50 & 0.22 & 0.0 & 0.31 & 0.26 & 0.44 & 69.2 & 8.8 & 3.9 & 0 & 5.4 & 4.6 & 7.7 \\
\hline 5.43 & 3.70 & 0.44 & 0.23 & 0.0 & 0.20 & 0.35 & 0.51 & 68.2 & 8.1 & 4.2 & 0 & 3.7 & 6.4 & 8.4 \\
\hline 5.49 & 3.91 & 0.54 & 0.24 & 0.03 & 0.29 & 0.26 & 0.22 & 70.8 & 10.3 & 4.3 & 0.6 & 4.9 & 5.0 & 3.9 \\
\hline
\end{tabular}

potato. 3. Catharsis. 4. Fifteen gr. thyroid extra daily.

Downloaded From: http://archinte.jamanetwork.com/ by a Western University User on 06/10/2015 
mixed diet ( 3 to 5 per cent.)," and their table shows many instances of a percentage higher than any that we have found except on a day of catharsis (see table).

Since the liver is the organ especially charged with the conversion of ammonia to urea, particularly that ammonia which may arise from putrefactive processes in the large intestine, ${ }^{19}$ it has been assumed that a high ammonia, unaccounted for by any unusual acid bodies in the urine, is a sign of liver inefficiency, ${ }^{20}$ and Falk and Hessky adopt this explanation of their findings, pointing out that the intolerance of the pregnant woman for levulose is a parallel indication.

TABLE 5.-Results of Metabolism Experiment in

\begin{tabular}{|c|c|c|c|c|c|c|c|c|c|c|c|c|}
\hline \multirow[b]{2}{*}{$\dot{0}$} & \multirow[b]{2}{*}{ 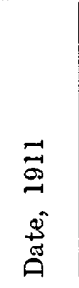 } & \multirow[b]{2}{*}{ 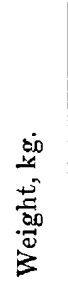 } & \multirow[b]{2}{*}{ 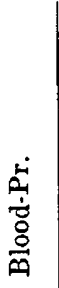 } & \multirow[b]{2}{*}{ 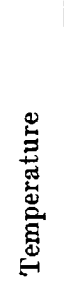 } & \multirow[b]{2}{*}{$\frac{\stackrel{00}{a 2}}{\underset{2}{2}}$} & \multirow[b]{2}{*}{ 苞 } & \multirow[b]{2}{*}{ Diet } & \multirow[b]{2}{*}{ 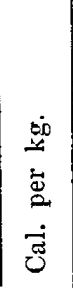 } & \multicolumn{4}{|c|}{ Urine Qualitative Examination } \\
\hline & & & & & & & & & $\frac{\stackrel{\Xi}{\Xi}}{\stackrel{0}{0}}$ & 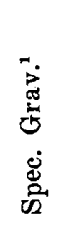 & 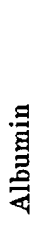 & 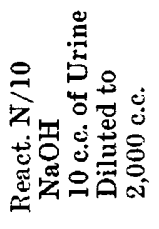 \\
\hline & Dec. & & & & & & & & & & & c.c. \\
\hline 1 & $5-6$ & $\cdots$ & & 98 & 100 & 22 & Ordinary hospital fare. & & 1700 & 1028 & $0^{1}$ & Ac. \\
\hline 2 & 6- 7 & ... & 97 & 98 & 108 & 24 & Ordinary hospital fare. & & 1470 & 1020 & 0 & $3.1 \mathrm{c}$. \\
\hline 3 & $7-8$ & .. & 117 & 98 & 112 & 24 & Milk, bread and butter. & 18 & 722 & 1032 & $\mathbf{0}$ & Ac. \\
\hline 4 & 8- 9 & 83.9 & 110 & 97.8 & 100 & 24 & Milk, bread and butter. & 20 & 612 & 1034 & 0 & Ac. \\
\hline 5 & $9 \cdot 10$ & 83.6 & 115 & 98.2 & 108 & 22 & Milk, bread and butter. & 19 & 570 & 1030 & $\mathbf{0}$ & 6.4 c.c \\
\hline 6 & $10-11$ & 83.1 & 105 & 97.4 & 100 & 24 & Milk, bread and butter. & 23 & 1330 & 1020 & 0 & $3.5 \mathrm{c.c}$ \\
\hline 7 & $11-12$ & 83.4 & 90 & 98 & 96 & 24 & Milk, bread and butter & 27 & 780 & 1027 & 0 & 6.0 c.c. \\
\hline 8 & $12-13$ & 84.1 & 96 & 97.8 & 92 & 24 & Milk, bread and butter & 29 & 780 & 1026 & 0 & 6.1 c.e. \\
\hline 9 & $13-14$ & 83.9 & 100 & 98.2 & 96 & 24 & Milk, bread and butter. & 30 & 750 & 1022 & $\mathbf{0}$ & Ac. \\
\hline 10 & $14-15$ & 83.6 & 106 & 97.8 & 96 & 24 & Milk and starchy foods & 27.4 & 760 & 1022 & $\mathbf{0}$ & Ac. \\
\hline 11 & $15-16$ & 83.4 & 94 & 97.8 & 100 & 24 & Milk and starchy foods & 27.4 & 800 & 1028 & 0 & Ac. \\
\hline 12 & $16-17$ & 83.6 & 94 & 98.4 & 100 & 24 & Milk and starehy foods & 27.4 & 667 & 1024 & 0 & Ac. \\
\hline 13 & $17-18$ & 84.1 & 98 & 98.4 & 100 & 22 & Milk and creatin foods & 27.4 & $670^{3}$ & 1022 & 0 & Ac. \\
\hline 14 & $18 \cdot 19$ & 84.1 & 98 & 98.2 & 96 & 24 & Ordinary hospital fare. & .... & 1140 & 1014 & $\mathbf{0}$ & Ac. \\
\hline
\end{tabular}

1. Acetone, albumin and diacetic acid absent. 2. Error probably on urea. 3. Some urine lost.

Heynemann, however, reviews all the signs of liver inefficiency which have been accepted by different observers, including urobilinuria, faulty fat metabolism, levulosuria, etc., and reaches the conclusion that none of these have been established. He cites, for example, work tending to show that all female subjects have a lower tolerance for levulose than have male subjects with whom the pregnant have so often been compared. Landsberg seems to dispose of the high ammonia as a sign of liver ineffi-

19. Folin: Jour. Biol. Chem., 1912, xi, 161.

20. See, for example, Ewing and Wolff: Amer. Jour. Obst., 1907, 1v, 289. 
ciency by showing that the ammonia runs parallel to the total acidity in such urines. The excess acid he thinks may originate in the fetus.

While we are quite prepared to admit the possibility of Landsberg's explanation, it must be remembered that he has in his own figures and we have in ours only a slight discrepancy in the absolute amount of ammonia nitrogen to be accounted for. As a matter of fact, we do not regard our absolute ammonia figures as high at all. It is only the relative or percentage amount which is high and that is partly explained at once by the lower total nitrogen excretion. Assuming, however, that this is

Normal Pregnancy. Case 3 (E. B.) Ninth Month

\begin{tabular}{|c|c|c|c|c|c|c|c|c|c|c|c|c|c|c|}
\hline \multicolumn{15}{|c|}{ Quantitative Urine Analysis of Nitrogen Fractions } \\
\hline 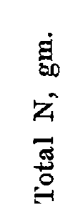 & 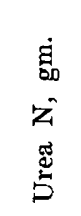 & 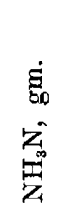 & $\begin{array}{l}\dot{g}_{0} \\
z_{j}\end{array}$ & 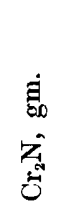 & 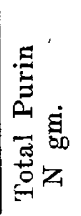 & 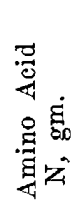 & 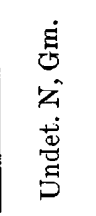 & 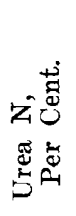 & 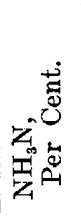 & 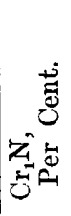 & 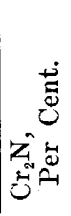 & 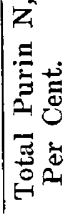 & 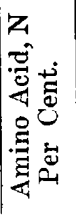 & 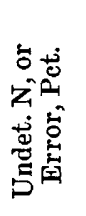 \\
\hline 14.28 & 12.58 & 0.53 & 0.43 & 0.22 & 0.50 & 0.27 & -0.25 & 88.1 & 3.7 & 3.0 & 1.6 & 3.5 & 1.9 & -1.8 \\
\hline 11.20 & 8.90 & 0.50 & 0.38 & 0.19 & 0.31 & 0.22 & 0.70 & 79.5 & 4.5 & 3.4 & 1.7 & 2.8 & 2.0 & 6.2 \\
\hline 10.37 & 9.18 & 0.50 & 0.40 & 0.17 & 0.59 & 0.31 & -0.78 & 88.5 & 4.8 & 3.9 & 1.6 & 5.7 & 3.0 & $-7.5^{2}$ \\
\hline 10.64 & 8.61 & 0.46 & 0.39 & 0.12 & 0.12 & 0.29 & 0.65 & 80.8 & 4.3 & 3.7 & 1.1 & 1.1 & 2.7 & 6.1 \\
\hline 8.06 & 6.54 & 0.34 & 0.25 & 0.08 & 0.31 & 0.24 & 0.30 & 81.0 & 4.2 & 3.1 & 0.8 & 3.7 & 3.0 & 3.7 \\
\hline 11.84 & 9.31 & 0.57 & 0.42 & 0.08 & 0.22 & 0.39 & 0.85 & 78.6 & 4.8 & 3.5 & 0.7 & 1.8 & 3.3 & 2.2 \\
\hline 10.15 & 8.10 & 0.53 & 0.33 & 0.04 & 0.45 & 0.27 & 0.43 & 79.8 & 5.2 & 3.2 & 0.4 & 4.4 & 2.6 & 4.2 \\
\hline 10.70 & 9.34 & 0.63 & 0.36 & 0.10 & $0.3 \mathrm{I}$ & 0.29 & -0.33 & 87.3 & 5.9 & 3.4 & 0.9 & 2.9 & 2.7 & -3.1 \\
\hline 7.95 & 6.44 & 0.45 & 0.26 & 0.08 & 0.59 & 0.24 & -0.11 & 81.0 & 5.7 & 3.3 & 1.0 & 7.4 & 3.0 & -1.4 \\
\hline 10.25 & 8.13 & 0.66 & 0.38 & 0.08 & 0.25 & 0.38 & 0.37 & 79.3 & 6.4 & 3.7 & 0.8 & 2.4 & 3.7 & 3.6 \\
\hline 11.03 & 8.57 & 0.66 & 0.41 & 0.02 & 0.50 & 0.45 & 0.40 & 77.7 & 6.0 & 3.7 & 0.2 & 4.5 & 4.0 & 3.6 \\
\hline 8.47 & 6.98 & 0.50 & 0.31 & 0.12 & 0.22 & 0.44 & -0.10 & 82.4 & 6.1 & 3.7 & 1.4 & 2.6 & 5.9 & -1.2 \\
\hline 5.88 & 4.56 & 0.36 & 0.20 & 0.18 & 0.20 & 0.29 & +0.09 & 72.6 & 6.1 & 3.4 & 3.0 & 3.4 & 4.9 & 1.6 \\
\hline 6.61 & 5.17 & 0.43 & 0.23 & 0.06 & 0.25 & $\cdots \cdots$ & $\cdots \cdots$ & 78.2 & 6.5 & 3.5 & 0.9 & 3.8 & $\ldots$. & $\cdots$ \\
\hline 9.82 & 8.03 & 0.51 & 0.34 & 0.11 & 0.34 & 0.31 & +0.16 & 81.4 & 5.3 & 3.5 & 1.2 & 3.6 & 3.3 & +1.6 \\
\hline
\end{tabular}

4. Oatmeal, bread, graham crackers, baked potato.

3. Fifteen gr. thyroid extract daily.

not sufficient explanation, is it not possible that the higher ammonia is due to a high relative (not high absolute) acidity? Suppose the fetus were drawing bases from the maternal blood more rapidly than acids, the effect would be to increase the ammonia in the urine of the mother, just as is known to occur when an excess of bases is excreted through the bowel. ${ }^{21}$

21. Cf. Steinitz: Jahrb. f. Kinderh., 1903, lvii, 689.

2la. Hoffström [Skand. Archiv. f. Physiol., 1910, xxiii, p. 326] indeed has shown that the fetus lays claim to the calcium of the food much more rapidly than to the sulphur and phosphorus. 
INFLUENCE OF CATHARSIS ON AMMONIA PERCENTAGE

On December 16 two of the three patients were given calomel, salts and high colonic irrigation for the purpose of preparing the bowel for the administration of creatin the next day (see below). The tables show that the volume of urine was much reduced in Case 2, a fact which we have ascribed to the reduced absorption from the bowel. The amount of creatinin shown indicates that there was no reduction in the endogenous metabolism as the result of this treatment, but the amount of total nitrogen shows clearly that there was a very great change in the amount of protein material absorbed during the twenty-four hours. Singularly enough, the absolute quantity of ammonia on the day of catharsis was the same as the day before; but the percentage amount was enormously increased on account of the low excretion of total nitrogen. The catharsis in this patient must have been unusually severe (note the loss in weight), but there was no visible contamination of the urine from the bowel. The same phenomenon is to be seen in Case 3 on the day of catharsis, the rise in percentage being, however, very small as compared with Case 2 , doubtless on account of a less complete purging. The absolute amount of ammonia was the same as the day before; and, by a coincidence, the same as for the corresponding day for Case 2. The rise in percentage for this day, while not more than might occur independently of such a cause, seems to be best explained by the fall in the total nitrogen. This emphasizes again the importance of great care in the interpretation of high ammonias.

\section{CREATININ NITROGEN}

The chemical history of this fraction of the nitrogenous waste from the body has not yet been fully revealed. It seems to be proportional in amount to the muscular development of the individual ${ }^{22}$ and therefore to be associated in some way with the functioning of this tissue, but not with the amount of work it does. ${ }^{23}$ It has been strenuously held by some that the creatinin of the urine bears no physiological relationship with the creatin which is always found in the watery extract of muscle and which is chemically so closely related to creatinin. ${ }^{24}$ But the recent experiments of Towles and Voegtlin ${ }^{25}$ on the subcutaneous administration of creatin to fasting dogs and to dogs with the Eck fistula and the observation of Myers and Fine ${ }^{26}$ that the daily output of the dog, cat

22. Shaffer: Am. Jour. Physiol., 1908, xxiii, 1.

23. Shaffer: Idem., xxii, 445; Von Hoogenhuyze and Verploegh, Ztschr. f. physiol. Chemie, 1905, xlvi, 415; Pekelharing and Von Hoogenhuyze, Idem., 1910, lxiv 262.

24. Folin: Hammersten's Festschrift 1906, p. 1; Von Hoogenhuyze and Verploegh, Ztschr. f. physiol. Chemie, 1908, lvii, I61.

25. Towles and Voegtlin: Jour. Biol. Chem., 1912, x, 479.

26. Myers and Fine: Jour. Biol. Chem., 1913, xiv, 9. 
and rabbit is roughly proportional to the percentage content of creatin in their muscles, go far toward proving a close relationship between them. Until this point is settled we shall not be able to appreciate the exact significance of creatinin; but it will be interesting at all events to see how its elimination in the pregnant woman compares with that in normal non-pregnant individuals.

Creatinin Coefficient. - The number of milligrams of creatinin nitrogen excreted in twenty-four hours, per milligram of body weight, is known, after Shaffer ${ }^{22,23}$ (loc. cit.) as the "creatinin coefficient." Shaffer's average value for " 37 supposedly normal individuals" was 8.1, maximum 11.7, and minimum 5.4. One of Shaffer's "pathological cases" was a woman in normal pregnancy. She was of "only fair muscular development, slender and active." Her creatinin coefficient in the seventh month of her pregnancy was 6.35 , early in the ninth month it was 6.75 , and one week before labor was 6.2 -all obtained on a creatin and creatinin-free diet. Shaffer does not state whether he regards this as a low coefficient, but does accede to the statement of Benedict and Meyers ${ }^{27}$ based on their study of the creatinin coefficient in insane but otherwise normal women that "the creatinin coefficient of women is, in general, lower than for men." Shaffer explains this as due to the relatively large amount of fat and smaller amount of muscular tissue in the average woman and expresses the belief that "sex per se has no significance." So far as we are aware no other coefficients for normal or non-pregnant women have been published. Neither Van Hoogenhuyze and ten Doeschate ${ }^{28}$ nor Heynemann, ${ }^{29}$ who have reported extensive studies in pregnant women, give the weights of their subjects.

From the results published by one of $u^{5}$ a short time ago, it is possible to calculate the coefficient for one case who was kept on a creatin and creatinin-free food for several weeks preceding her labor. Taking the average of twenty-one days the excretion of creatinin nitrogen was $0.24 \mathrm{gm}$. The average net weight for this period was 69.2 kilograms, which gives a coefficient of 3.5 - but little higher than that found by Benedict and Myers for a woman convalescent from typhoid (namely, 3.1 ).

The average coefficients for that portion of the period of observation when the subjects of the present series were on a creatin and creatininfree food (eleven days) are: 4.7 for Case 1, 3.2 for Case 2 and 4.7 for Case 3. It is probable that all four of these cases carried more body fat

27. Benedict and Myers: Am. Jour. Physiol., 1907, xviii, 377.

28. Von Hoogenhuyze and ten Doeschate: Ann. de Gynec., 1911, Series 2, VIII, 17 and 97.

29. Heynemann: Ztschr. f. Gebürtsh. u. Gynäk., 1912, Ixxi, 110. 
than Schaffer's "slender women," which no doubt explains in part the discrepancy between his coefficient and ours. Even his case, however, shows a lower coefficient than the average for a normal man, and, if sex per se plays no part, lower also than for the non-pregnant woman.

One reason for this will be apparent at once; namely, the dilution, if we may call it such, of the body weight by the uterine contents. Myers and Fine ${ }^{26}$ have recently confirmed for the cat the observation originally made by Dörner ${ }^{30}$ for rabbits, and later by Mellanby ${ }^{31}$ for both rabbits and chickens, that young individuals have less creatin in their muscles than adults of the same species; and Rose ${ }^{32}$ has found the creatin content of the muscles of the new-born infant to be only 0.07 per cent., as against 0.3 per cent. for the adult. Mendel and Leavenworth ${ }^{33}$ have furnished us the only determinations yet made for the embryo, in the case of the pig, reporting .03 per cent. for an embryo of $265 \mathrm{~mm}$. length as compared with 0.45 per cent., reported by Van Hoogenhuyze and Verploegh ${ }^{34}$ for the muscles of the grown animal. Presumably the same relationship would hold for the human embryo of corresponding age, and the creatin content would gradually increase up to 0.07 per cent. found for the newborn infant.

We have been unable to find any analyses of the pregnant uterus for creatin. Judging by the analysis of the non-striated muscle of the stomach, bladder, ${ }^{35}$ retractor muscle of the penis ${ }^{36}$ and for the intermediate type of muscle in the heart, ${ }^{37}$ it should be considerably less than that of striated muscle.

If creatin is the mother substance of creatinin in the urine, therefore, neither the fetus nor the uterus may be supposed to contribute much of it. The placenta, presumably, and the membranes and the fluids certainly, would contribute none at all. All of this weight would serve, as does the body fat, to reduce the creatinin coefficient. Even if creatinin does not come from creatin, we know from the fact that the elimination of creatinin by the new-born child is very small, that the production of this substance by the fetus must be negligible.

Support for this view is found also in the following observations, some of them unpublished, on a pregnant $\operatorname{dog} .{ }^{12}$

30. Dorner: Ztschr. f. physiol. Chem., 1907, lii, 264.

31. Mellanby: Jour. Physiol., 1908, xxxvi, 447.

32. Rose: Jour. Biol. Chem., 1911, x, 265.

33. Mendel and Leavenworth: Am. Jour. Physiol., 1908, xxi, 100.

34. Von Hoogenhuyze and Verploegh: Ztschr. f. physiol. Chemie, 1905, xlvi, 432.

35. Saiki: Jour. Biol. Chem., 1908, iv, 483.

36. Buglia and Constantino: Ztschr. f. physiol. Chemie, 1912, lxxxi, 122.

37. Fürth, V., and Schwarz: Biochem. Ztschr., 19ll, xxx, 413. 


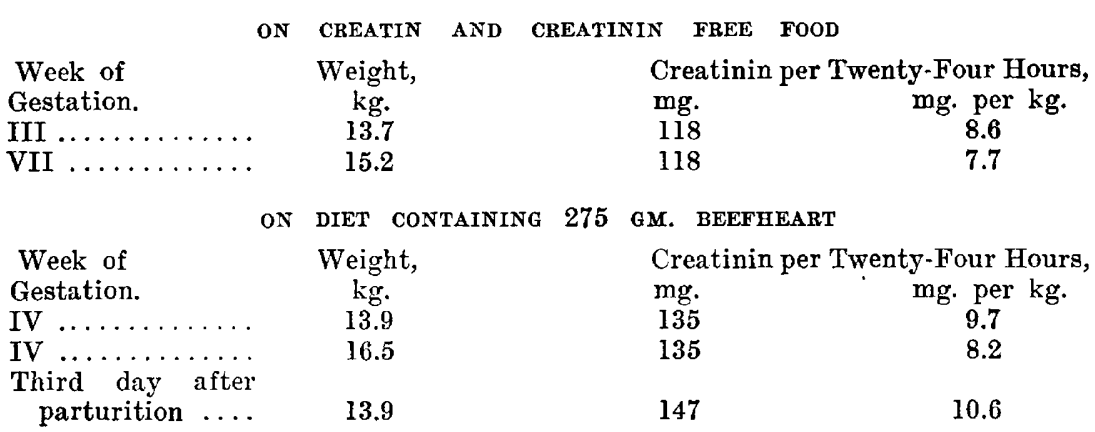

The return of the weight to $13.9 \mathrm{~kg}$. so soon after delivery of the pups shows that the increase in weight in pregnancy was due mainly, if not entirely, to the product of conception and not to body fat. The rise of the coefficient after parturition is due to the discharge of some creatin from the involuting uterus in the form of creatinin.

This explanation may not be wholly adequate for the human organism. It will be impossible to determine whether it is or not until a rigid comparison is made between pregnant and non-pregnant women, whose weights are known, on proper diets.

Our observations on these cases having terminated nearly three weeks previous to delivery, the rise in creatinin excretion which was previously reported $d^{5}$ as occurring in the last week or ten days of pregnancy does not appear here.

The creatinin and creatin metabolism just before and just after parturition has been fully discussed in former publications. Heynemann's work within the year has confirmed the conclusions we had already reached as to most of the points in discussion, and particularly as to the bearing which any alterations in this metabolism in normal pregnancy might have on the question of liver inefficiency. $\mathrm{He}$ argues, as did Murlin, that if it were shown satisfactorily that the liver does produce creatinin from creatin, and if it were shown further that in pregnancy the increase in creatin output is accompanied by a decrease in creatinin output, we might feel justified in accepting this as a sign of liver inefficiency, as do Van Hoogenhuyze and ten Doeschate. The former proposition, however, seems to be growing less rather than more secure as evidence accumulates, and on the latter there is no evidence at all as yet; for the tables of Van Hoogenhuyze and ten Doeschate do not show a decrease in the creatinin any more than do those of Heynemann or Murlin, and if they had followed the excretion of creatinin on a constant diet up to the day of parturition it is probable that they also would have seen a rise in this constituent rather than a fall. Heynemann's figures for the creatinin output vary so much from day to day that it is impossible to say whether his results confirm or refute his argument. 
We are not inclined to lay much stress on the results from Eck fistula, especially if the hepatic artery be not tied; for Fischler ${ }^{38}$ has shown that neither the formation of bile nor the carbohydrate tolerance is affected by this operation. Nevertheless, the newer experiments of Towles and Voegtlin ${ }^{25}$ seem to show quite conclusively that whatever damage is done to the metabolic processes by this operation the transformation of creatin to creatinin is not one which suffers. They conclude that the liver is not an organ of prime importance in connection with the metabolism of these substances.

\section{CREATIN NITROGEN}

There is general agreement among the observations of Van Hoogenhuyze and ten Doeschate, Heynemann and ourselves as to the appearance of creatin in the urine of late pregnancy, even on a creatin and creatininfree food. The three cases of the present series fall into line with previous ones. Case 2, however, shows less creatin than the others, and we can find no other explanation than the fact that the patient took more food per kilogram of body weight than the others. The appearance of creatin on the ninth and tenth days of the period may be the result of thyroid feeding on the eighth and ninth days. All the patients received on these days 15 grains of dried thyroid extract. This was the only case which showed any effect, and the only effect which any case showed.

It is possible that by feeding a larger amount of carbohydrate the urine could have been kept clear of creatin throughout. Mendel and Rose $^{39}$ have shown that for the rabbit at least a small amount of carbohydrate is sufficient to prevent or to diminish greatly the excretion of this constituent in the urine of otherwise fasting animals. As suggested in a former paper, ${ }^{\overline{5}}$ it is possible that the appearance of creatin in the urine of late pregnancy is due to the rapid diffusion of dextrose, the carbohydrate of the blood, through the placenta and its fixation or combustion there, thus depriving the maternal organism of its protecting influence. On December 16, the twelfth day of the experiment period and the day following thorough cleansing of the bowel, we fed two of the three patients (Cases 2 and 3 ) each $1 \mathrm{gm}$. of pure creatin, ${ }^{40}$ the object being to test the capacity of the pregnant organism to eliminate or to utilize this form of nitrogen. Out of the $320 \mathrm{mg}$. of nitrogen administered, we recovered only about $60 \mathrm{mg}$. from Case 3 , and none at all from Case 2 (a small quantity of urine was lost, however, from Case 3). Our hope was that by thoroughly cleansing the bowel and thereby reducing the

38. Fischler, cited by Wolf: Jour. of Biol. Chem., 1912, x, 473.

39. Mendel and Rose: Jour. Biol. Chem., 1911, x, 213.

40. The creatin was prepared for us by Dr. Stanley R. Benedict who also sug. gested the catharsis as a preparation for its administration. 
possibility of bacterial decomposition a larger amount of the creatin fed might pass into the urine. The experiment is not very conclusive, but is in accordance with the previous results of Folin and Van Hoogenhuyze and Verploegh to the effect that creatin in the food is largely destroyed or is retained in the body of normal persons.

\section{TOTAL PURIN NITROGEN}

The total purin nitrogen excreted includes not only the nitrogen of uric acid, but also that of the less completely oxidized purin bases, hypoxanthin, xanthin, adenin and guanin, and that of any methylated compounds of this series like caffein, theobromin, etc.

Excluding coffee, tea, etc., which might contribute methylated compounds to the urine, the amount of total purin nitrogen excreted on a purin-free diet is the best measure we have of nuclein metabolism in the body, i. e., of the destruction of cell nuclei. Following the terminology of Burian and Schur, ${ }^{41}$ this is known as endogenous nuclein metabolism.

There is still a difference of opinion whether the uric acid should be regarded as an end stage in the metabolism of nucleins ${ }^{42}$ or as only an intermediary stage on the way, by uricolysis and oxidation, to urea. ${ }^{43}$ Concerning the other purins there is no doubt that they could be oxidized to uric acid if opportunity offered, so that the amount in which they appear in the urine is more or less fortuitous.

'The amount of purin nitrogen excreted by the pregnant subject is a matter of some interest because of the important part which nuclei play in embryogenesis and histogenesis.

Our normal subjects were kept for eleven days on a diet which was nearly, if not quite, purin-free. Tea, coffee and cocoa were excluded. The output of total purin nitrogen, then, for these eleven days is a measure-a rough one probably - of the extent to which cells are being broken down and their nucleins destroyed. The tables give the average elimination for the entire fourteen days. When meat was ingested on the first two and last days, considerably more purin was found in the urine. Taking the average of the purin-free days we find that Case 1 eliminated on the average $0.36 \mathrm{gm}$., Case 2, $0.24 \mathrm{gm}$. and Case $3,0.31$ gm. purin nitrogen; or, expressed as a coefficient in milligrams per kilogram of body weight, Case 1, 4.8; Case 2, 3.7, and Case 3, 3.7.

The only experiments which we have been able to find on purin-free diets in which the total purin nitrogen was determined by a reliable method, are those of Cathcart ${ }^{44}$ (Camerer-Arnstein method) on the

41. Burian and Schur: Pflüger's Arch. f. path. Anat., 1901, lxxxvii, 239.

42. Wiechowski: Arch. f. exper. Path., 1909, lx, 185.

43. Cf. e.g. Frank and Schittenhelm: Ztschr. f. physiol. Chemie, 1909, Jxiii, 269.

44. Cathcart: Biochem. Ztschr., 1907, vi, 109. 
professional faster Beauté, and those of Mendel and Lyman ${ }^{45}$ (method of Krüger and Schmid) on normal male subjects.

Beauté, on an egg and milk diet, excreted $0.194 \mathrm{gm}$. of total purin nitrogen just before a fast of fourteen days, and $0.166 \mathrm{gm}$. on the same diet just after the fast. In milligrams per kilogram of body weight the coefficient was 3.0 and 2.8, respectively.

In Mendel and Lyman's experiments their subject, W. H. H., excreted $0.139 \mathrm{gm}$. total purin nitrogen on a purin-free diet, and J. F. L. excreted $0.144 \mathrm{gm}$. The coefficients per kilogram were 2.4 and 2.1 , respectively.

It appears that the pregnant woman excretes not a little more purin nitrogen per unit of weight than does the normal man. It has long been known that the new-born infant exeretes much more uric acid per unit of weight than does the adult, and more also in the relation to the urea excretion. Both Flensburg and Rensing ${ }^{46}$ find the explanation of this fact in the hyperleukocytosis and the consequent high destruction of leukocytes going on in the infant's body during the early days of extrauterine life. This hyperleukocytosis occurs also in the fetus and it is known that the leukocytes are destroyed both in the spleen and in the connective tissues. ${ }^{47}$ Hence we should expect a rapid production of both uric acid and of purins which must be eliminated through the maternal system, since Mendel and Leavenworth ${ }^{48}$ found no uricolytic enzyme in the embryo pig.

\section{AMINO-ACID NITROGEN}

Following the caution of Henriques and Sörensen, we wish to emphasize the fact that the fraction of nitrogen actually determined by the titration method includes some nitrogen in the form of polypeptids or other combinations; nevertheless it is customary to include all such freeacid groupings as can be set free for titration by neutral formaldehyd solution, after removal of ammonia, under this designation, and the method of Henriques and Sörensen certainly gives us as close an approximation to the free amino-acids as any that we have at present. ${ }^{49}$

Recent determinations of the amino-acid nitrogen in pregnancy by Falk and Hessky ${ }^{15}$ and by Landsberg ${ }^{13}$ working by the so-called "new method," show that this fraction is slightly increased over the amount found in the urine of the non-pregnant woman on a similar diet. The former observers found the average from non-pregnant subjects to be 0.17 to $0.29 \mathrm{gm}$. in twenty-four hours, or 1.9 to 2.8 per cent. of the total

45. Mendel and Lyman: Jour. Biol. Chem., 1910, viii, 115.

46. Quoted by Czerny and Keller: Ernährung des Kindes, 1906, i, 216.

47. Minot: In Keibel and Mall's Embryology, 1911, ii, 504.

48. Mendel and Leavenworth: Am. Jour. Physiol., 1907, xx, 97.

49. A comparison of the gasometric method of Van Slyke with the titration method of Henriques and Sörensen has been made on a variety of urines by Levene and Van Slyke. Jour. Biol. Chem., 1912, xii, 309. 
nitrogen. Landsberg reports 0.4 to $0.48 \mathrm{gm}$., or 2.5 to 3.0 per cent., of the total nitrogen. These figures agree fairly well with the percentage given by Henriques ( 2.2 per cent.) and with that by Levene and by Van Slyke $^{49}$ for normal urine.

In normal pregnancy Falk and Hessky find from 2 to 8 per cent. of the total nitrogen may be present in the form of amino-acids and Landsberg makes the figures from 0.23 to $0.67 \mathrm{gm}$., or 2.4 to 4.9 per cent. of the total. It will be observed that the absolute amount ranges even lower in the pregnancy urine than in that from non-pregnant women. Landsberg himself is disinclined to lay much stress on the very small increase which some cases show, and correctly refers a portion of the relative increase to the lower total nitrogen.

It will be seen from Tables 3,4 and 5 that our results also show but a small increase over the amount considered normal. With Case 1 we have as the average of thirteen days, $0.47 \mathrm{gm}$. amino-acid nitrogen, or 4.4 per cent. of the total; with Case 2 , for fourteen days, 0.26 , or 5 per cent. of the total; and with Case 3 for thirteen days, $0.31 \mathrm{gm}$., or 3.3 per cent. of the total. All of these come within the range given by Landsberg. We call special attention to the fact that the lowest average absolute amount $(0.26 \mathrm{gm}$.) is at the same time, owing to the low output of total nitrogen, the highest relative or percentage amount ( 5 per cent.). This shows how much the nitrogen retention may have to do with the percentage.

The agreement among all observers using a reliable method therefore is very close, and the lower figures should supercede those of Van Leersum, ${ }^{50}$ who used his own modification of the old SchöndorffPfaundler method, and those of other observers who have denominated the rest nitrogen, after determination of urea, ammonia, creatinin and uric aid, as the "amino-acid nitrogen."

Falk and Hessky consider that their figures show a sufficient increase to indicate a distinct disturbance of metabolism and place their results on the side of those who regard the liver as the seat of this functional disturbance. In refutation of this view it is sufficient at this time to cite the new work of Folin ${ }^{51}$ and his pupils and that of Van Slyke and Meyer, ${ }^{52}$ which appear to demonstrate conclusively that neither the intestine nor the liver has any more to do with deamination of absorbed proteins than have other tissues, if they have as much. High amino-acid nitrogen, therefore, can no longer be cited as proof of defective deamination in the liver.

50. Van Leersum: Biochem. Ztschr., 1908, xi, 121.

51. Folin and Denis: Jour. Biol. Chem., 1912, xii, 87 and 141.

52. Van Slyke and Meyer: Jour. Biol. Chem., 1912, xii, 399. 
It is only where an absolute increase of one- or two-tenths of a gram of amino-acid nitrogen or a relative increase of more than 2 per cent. can be shown, that any explanation, other than that of individual variation, analytical error or redistribution caused by retention of urea nitrogen, is called for. While we have no non-pregnancy cases for direct comparison, we doubt very much whether our results show any further departure than this. If, however, we accept the slightly higher results of Falk and Hessky we believe that we are bound to search for the explanation in some physiological peculiarity of pregnancy before we declare the result a pathological one.

In attempting to account for the condition of minus nitrogen balance which occurs in the dog at about the time corresponding to the period of morning sickness in the woman, one of us, ${ }^{53}$ three years ago, offered the hypothesis that this period "simply marks the culmination of the more or less indiscriminate action of enzymes produced by the fetus" (fetal placenta) before the maternal placenta had been elaborated for the purpose of limiting the enzymes. Bar $^{54}$ had suggested a similar explanation (une veritable mobilization des albumins) for the loss of nitrogen, but did not commit himself as to the part played by the placenta.

Everything that we know about the implantation of the ovum certifies to its capacity to digest by proteolytic enzymes the uterine mucosa, and the morphological pictures which are presented by the process of vilus formation $^{55}$ bear witness that the trophoblastic cells which become the syncytial layer on the villus retain this capacity for a considerable time. ${ }^{50}$ The demonstration by Graefenburg ${ }^{57}$ of such enzymes in the human placenta, especially in the early months of pregnancy, and the recent discovery of Abderhalden ${ }^{58}$ of enzymes in the blood of the pregnant woman, dog, cow and other animals, capable of splitting placental proteins, constitute significant support for the general view. Williams and Pearce ${ }^{59}$ have found that these enzymes occurring in the blood of the pregnant woman are not specific, but are capable of acting on other proteins as well, and it is our belief that their presence in the blood is, as Abderhalden ${ }^{60}$ admits to be possible, "simply a consequence of the commerce going on between mother and fetus, and signify only that a

53. Murlin: Am. Jour. Physiol., 1910, xxvii, 177.

54. Bar: Lecons en pathologie obstetrical, Paris, 1907, ii, 288.

55. Bruce and Teacher: Contributions to the Study of the Early Development and Imbedding of the Human Ovum; Glasgow, 1908.

56. Marshall: Physiology of Reproduction, New York, 1910, p. 484.

57. Graefenburg: Ztschr. f. Gebürtsh. u. Gynäk., 1910, lxv, 1.

58. Abderhalden and Kiutsi: Ztsehr. f. physiol. Chemie, 1912, lxxxvii, 4.

59. Williams, P. F., and Pearce, R. M.: Proc. Soc. f. Exper. Biol. and Med., 1913, x, 73.

60. Abderhalden: Ztschr. f. physiol. Chem., 1912, lxxxi, 96. 
very extensive transformation must take place before the material of the maternal blood can be carried over to the fetal blood." The action of placental enzymes has been offered by one of us also as an explanation of the higher amino-acid content of the urine of pregnancy. ${ }^{61}$ If products of proteolysis going on in the placenta were diffusible into the maternal blood some of these products would pass to the kidney before there was an opportunity of their being deaminated or stored in the maternal tissues. 'The amount passing out by the kidney would not depend in any special way on liver function, but on the quantitative relation between their escape from the placenta and their destruction or fixation in the maternal tissues.

\section{UNDETERMINED NITROGEN}

Adding together all these fractions - urea, ammonia, creatin, creatinin, total purin and mono-amino-acid nitrogens - there yet remains a small fraction undetermined. Of course, we must recognize the fact frankly that what remains may be error. If an error of only 0.5 per cent. should occur in each of the determinations made and all of the errors were by chance in the same direction, there might be an apparent undetermined nitrogen of over 3 per cent. Assuming, however, that in most instances such errors would counterbalance each other, we find left in almost all of the urines we have examined an undetermined fraction of from 3 to 9 per cent. A very small part is in some cases due to albumin; in a few urines we have determined what Henriques and Sörensen call the polypeptid nitrogen; i. e., extra amino-acid nitrogen after digestion of the urine with strong hydrochloric aid. The indications are that this would account for a considerable part of what we have called in our tables the "undetermined nitrogen." Henriques and Sörensen have found such a fraction in normal urines. Falk and Hessky ${ }^{15}$ have determined the polypeptid nitrogen in the urine of both pregnant and non-pregnant women and have found an increase of from two- to three-fold the normal amount in the former. Their percentage figures show about the same range as our percentage figures for the undetermined nitrogen. They believe the increase is due to an extra production of glycocoll in combination with aromatic and hydro-aromatic compounds similar to hippuric acid. We have no data from nonpregnant subjects with which to compare our results for this fraction. Granting, however, that it is increased, it seems to us more probable that compounds of the nature of oxyproteic acid, which Salomon and Saxe ${ }^{\mathbf{6 2}}$ have demonstrated to be present in the urines of normal preg-

61. Murlin: Am. Jour. Physiol., 1911, xxviii, 450.

62. Salomon and Saxe: Cited by Falk and Hessky. See note 15. 
nancy in larger quantity, or the non-dialysable substances which Savarée ${ }^{63}$ found to be increased in such urines, are responsible.

The fact that the polypeptid nitrogen falls within twenty-four hours after delivery, as shown by Falk and Hessky, we should interpret to signify that it has its source in some function or process which ceases ordinarily with complete delivery of the child and placenta. This fact alone we should think would be sufficient to absolve the liver from responsibility quite aside from the new evidence that this organ has no special function to perform in relation to amino-acids or polypeptids; for it is difficult to see how it could recover its function completely in twenty-four hours. Still less could it be supposed to recover within this time if autolytic processes or degeneration of any other type within the liver parenchyma were the determining cause. Falk and Hessky were unable to find any polypeptid nitrogen in the press-juice of a fresh placenta and concluded from this that the placenta could not be the source of such bodies in the urine. Forty per cent. of the total nitrogen in this press-juice was in the form of amino-acid. This is an important fact in connection with the source of amino-acid nitrogen of the urine. Suppose, however, the amino-acids were to escape from the placenta together with proteolytic enzymes, some of which have been proved to be reversible in their action, i. e., can build up polypeptid compounds as well as split them into their component amino-acids. Might not synthetic compounds be formed either in the circulation or in the kidney which would pass through into the urine? The sudden decline of this fraction after parturition, at all events, would seem to be better explained by a fetal (placental) origin than by a maternal origin.

\section{SUMMARY AND CONCLUSIONS}

1. In a perfectly normal pregnancy and puerperium the percentage of ammonia nitrogen in the urine before and after labor shows but slight differences and lies within normal limits (4 to 6 per cent.), except for one or two days immediately following delivery, when it is slightly increased ( 7 to 10 per cent.).

2. Further evidence is presented that high ammonias may be encountered in normal cases due to contamination of the bladder. Irrigation of the bladder twice in twenty-four hours with saturated solution of boric acid caused reductions from $2.27 \mathrm{gm}$. to $1.33 \mathrm{gm}$. and from 1.07 gm. to $0.68 \mathrm{gm}$. ammonia nitrogen in twenty-four hours, the food and total nitrogen being the same.

3. Complete nitrogen partitions for three normal cases over a period of fourteen days in the ninth month of pregnancy are given. From these

63. Savare: Hoffmeister's Beitr. z. chem. Phys. u. Path., 1907, ix, 401. 
results and from those of other cases previously reported, we deduce the following:

4. The percentage of total nitrogen eliminated as urea by a pregnant woman in the last month is somewhat lower than from a non-pregnant person, due largely to the retention of nitrogen for growth of the product of conception. The average for our three cases for fourteen days is $\mathbf{7 6 . 6}$ per cent. The range for six cases is from 70.8 per cent. to 79.4 per cent.

5. The ammonia nitrogen in perfectly normal pregnancies, in which the retention of nitrogen is large and the total nitrogen in the urine consequently small, may range as high as 12 per cent. of the total and be unaccompanied by any unfavorable symptoms. Immediately after severe catharsis it may reach the height of 17 per cent., because of the diminished absorption of nitrogenous food from the alimentary tract, and consequently diminished excretion of total nitrogen. For this reason and because of the variations in the elimination of total nitrogen due to variations in the diet, it is inadvisable to rely on percentage figures in the determination of the ammonia, a point long ago insisted on by $F$. Miiller. The absolute values are much more reliable. In our experiments the absolute amount varies but slightly from day to day, and previous to delivery never exceeded $0.88 \mathrm{gm}$. in urine known to be uncontaminated. From these and earlier studies we are disposed to look on any amount up to $.012 \mathrm{gm}$. ammonia nitrogen per kilogram of body weight in the twenty-four-hour urine as well within normal limits.

6. The creatinin coefficient of normal pregnancy is much lower than the creatinin coefficient of normal male subjects and is probably lower than that of normal non-pregnant women. This is due in part to the "dilution" of the body mass in pregnancy with material (fetus, fluids, membranes, uterine muscle, ${ }^{64}$ etc.) which contain little or no creatin.

7. The occurrence of creatin in the urine of normal pregnancy is confirmed in the present cases. Its appearauce, however, seems to be dependent, to some extent at least, on the amount of food taken.

8. The total purin nitrogen is slightly higher in the urines of normal pregnancy than in the urines of normal male subjects on similar diets. An explanation is found in the same facts which account for the high elimination of uric acid by the new-born infant.

9. The amino-acid nitrogen, as determined by the improved formol titration method, is but slightly increased above the amount considered normal in the urines of non-pregnant subjects. This slight increase may

64. According to E. Mellanby [Proc. Roy. Soc. (B) 1913, lxxxvi, 88], the uterine muscle contains no creatin at all, and that it cannot be the source of the increased output of creatin in urine postpartum Mellanby believes he has demonstrated by collection of urines after hysterectomy. 
be accounted for by supposing that proteolytic products, derived either from the placenta or from maternal tissues by action of placental enzymes, are carried by the circulation in larger amounts than usual to the kidney which is permeable to them.

10. The undetermined nitrogen is probably to be accounted for by polypeptid bodies, including oxyproteic acids.

11. In general, we believe that peculiarities in the composition of the urine of normal pregnancy as regards its nitrogenous constituents may be accounted for on purely physiological grounds. 